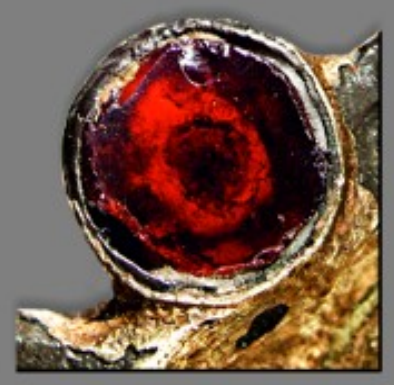

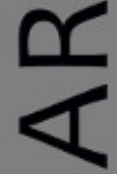

$\sim$

ш
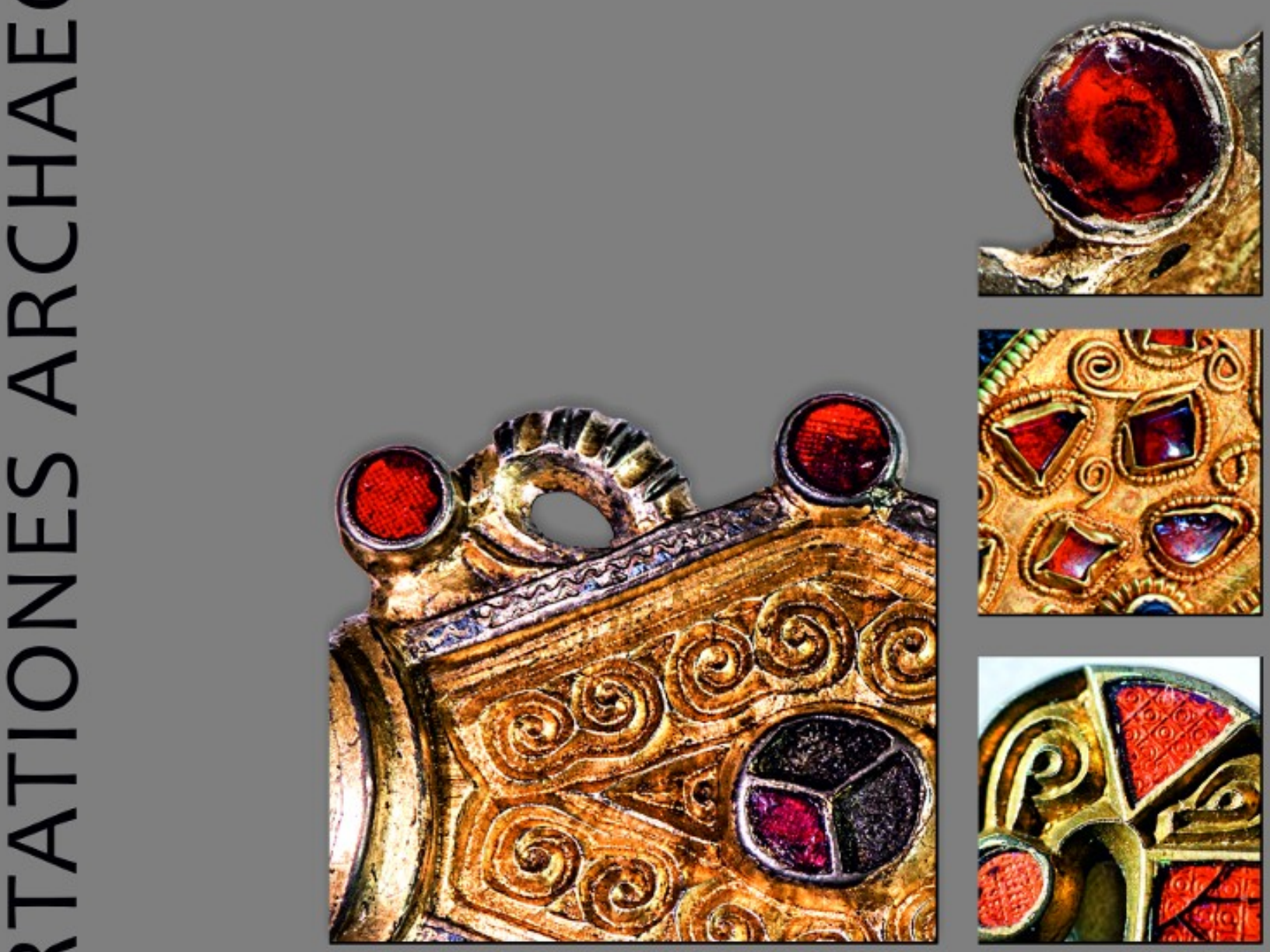

E

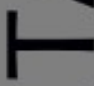

œ

山

n

ก

$\overline{0}$
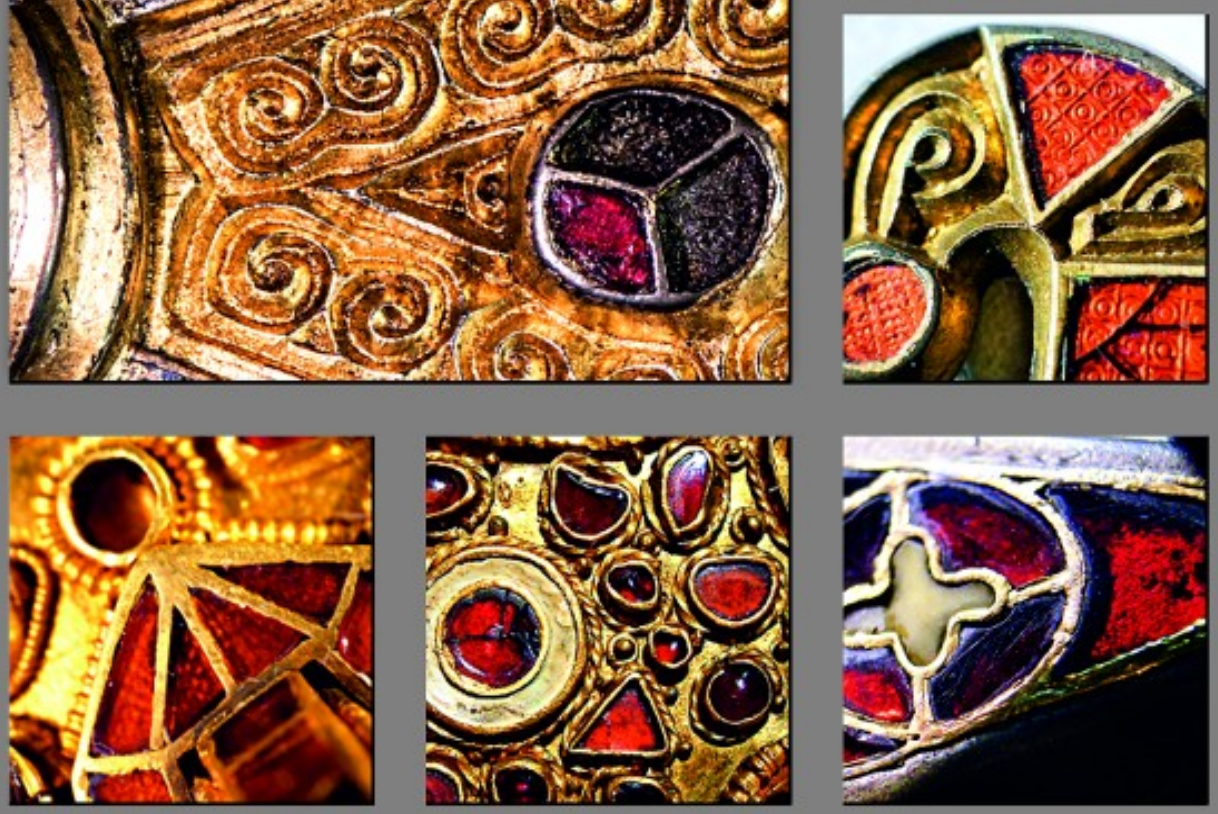

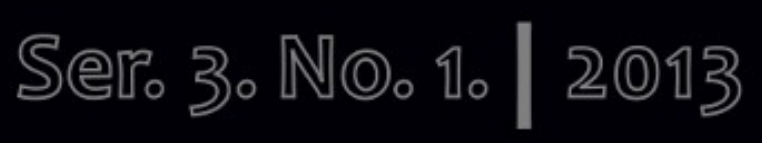




\section{Dissertationes Archaeologicae ex Instituto Archaeologico}

Universitatis de Rolando Eötvös nominatae Ser. 3. No. 1.

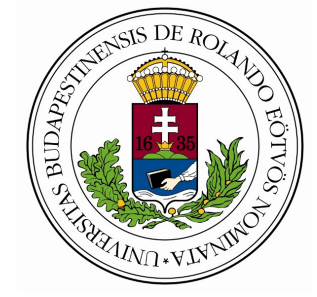

Budapest 2013 
Dissertationes Archaeologicae ex Instituto Archaeologico

Universitatis de Rolando Eötvös nominatae

Ser. 3. No. 1.

Editor-in-chief:

DÁvid BARTUS

Editorial board:

LÁSZLÓ BARTOSIEWICZ

LÁSZLÓ BORHY

ISTVÁN FELD

GÁBOR KALLA

PÁL RACZKY

Miklós SzABÓ

TIVADAR VIDA

Technical editors:

DÁvid BARTuS

GÁBOR VÁCZI

ANDRÁs BöDŐcs

Proofreading:

Zsófia KondÉ

SzILvia SzÖLlősI

Available online at http://dissarch.elte.hu

Contact: dissarch@btk.elte.hu

\section{$\underline{\text { PKP }}$ \\ PUBLIC \\ KNOWLEDGE \\ PROJECT}

(C) Eötvös Loránd University, Institute of Archaeological Sciences

Budapest 2013 


\section{Contents}

\section{Articles}

Melinda TORBÁGYI - István VIDA

The coin hoard of Abasár

Anikó BózsA

21

Roman mirrors from a private collection in the Hungarian National Museum

Lajos JuHÁsz

45

The Biesheim cameo - a reinterpretation

\section{Methods}

Péter CsIPpÁN

$A z$ állatcsont, mint információhordozó leletanyag

Kata DÉvAI

Terminológiai alapfogalmak régészeti korú üvegtárgyak elemzéséhez

Lőrinc TimáR - Zoltán Czajlik - Sándor Puszta - Balázs Holl

$3 D$ reconstructions using GPR data at the Mont Beuvray

\section{FIELD REPORTS}

Zsolt MESTER

Excavation at a new Upper Palaeolithic site of the Eger region (Northern Hungary)

László BORHY - Dávid BARTus - Emese SzÁmadó

Short report on the excavations at Brigetio (Szőny-Vásártér) in 2013

Dénes HulLÁm - Zsófia RÁcz

Report on the participation of the Eötvös Loránd University at the Wielbark Archaeological Field School in Malbork-Wielbark, Poland

Gábor VÁczi - Dávid BARTus

Short report on the excavations at the site Makó - Igási Ugar

Maxim MoRdovin

Short report on the excavations in 2013 of the Department of Hungarian Medieval and Early Modern Archaeology (Eötvös Loránd University, Budapest)

\section{THESIS ABSTRACTS}

Kitti KÖHLER

Biological reconstruction of the Late Neolithic Lengyel Culture 
Cultural connections and interactions of Eastern Transdanubia during the Urnfield period

Orsolya LÁNG

Urban problems in the civil town of Aquincum: the so-called „northern band”

Nikoletta SEY

Questions of bronze workshops in Roman Pannonia

Kata DÉvaI

Glass vessels from Late Roman times found in graves in the Hungarian part of Pannonia

Eszter HORvÁTH

Gemstone and glass inlaid fine metalwork from the Carpathian Basin:

the Hunnic and Early Merovingian Periods

Gergely SzEnTHE

Vegetal ornaments in the Late Avar decorative art

Péter LANGó

Relations between the Carpathian Basin and South East Europe during the 10th century.

The evidence of the minor objects

Ciprián HoRvÁTH

The Cemeteries and Grave Finds of Györ and Moson Counties from the Time

of the Hungarian Conquest and the Early Árpádian Age

András Sófalvi

The border- and self-defence of Szeklers from the Medieval Age till the Age of Principality.

Castles and other defence objects in the settlement history of Udvarhelyszék 


\title{
Glass vessels from Late Roman times found in graves in the Hungarian part of Pannonia
}

Kata DÉvai

MTA-ELTE Research Group for Interdisciplinary Archaeology

Eötvös Loránd University

kata.devai@gmail.com

\begin{abstract}
PhD thesis submitted in 2013 to the Archaeology Doctoral Programme, Doctoral School of History, Eötvös Loránd University, Budapest under the supervision of László Borhy.
\end{abstract}

\section{The topic and the purpose of the dissertation}

The main goal of the dissertation is to give a detailed presentation of late Roman glass ves sels found in graves in the Hungarian part of Pannonia and also to set up a typology considering colours, quality, details and decorations, which fields have not been investigated in the Hungarian research so far. The secondary goal is to analyze the chronological and geographical diversity of glass types, which leads to the definition of tendencies in the usage of glass and the areas supplied by a certain workshop.

Thousands of graves in Pannonia, in which several glass finds were found can be dated to the late Roman period. In the dissertation only those graves were analyzed that belong to the current territory of Hungary. As a result, only Pannonia Prima and Valeria provinces were studied.

The dissertation deals with the graves from the beginning of the 4th century AD to the mid dle of the 5th century AD, the surrender of Pannonia was not regarded as a closing date. The possibility of the continuation of Roman type glass production in the 5th century AD has also been observed. Certain specimens found in the Barbaricum outside the borders of the province can be identified as Roman type products due to similar production techniques, shapes, colours, qualities and decorations. However, these are not included in the catalogue. Since the proper investigation of such essential characteristics as colour, quality, design, detail and decoration can solely be carried out by personal observation, only those finds are listed in the dissertation which have been examined this way. Unfortunately no uniform terminology of glass objects has been provided in Hungary up to this day and drawings do not reflect the exact details of the vessels either. Therefore, those objects which have been published before but could not be observed personally in the framework of the research were not included in the dissertation.

A typology based on the function of glass objects has been applied generally since the 1990s. According to S. M. E. van Lith and K. Randsborg the glass vessels can be divided into three basic groups within which six subgroups can be differentiated. Classifying the vessels by studying their shapes does not provide sufficient information hence the analysis of production 
techniques, colours, quality of the materials and forming of the parts of the vessels is inevitable. In the dissertation a five-stage scale has been used to rate the quality of the materials. The catalogue lists drawings of intact vessels and definable fragments. The markings of the decorations and the details of the objects are included in the appendix.

\section{The structure of the dissertation}

The first chapter of the dissertation is the Introduction, which consists of three parts: the first part introduces the topic and the goals of the dissertation (1.1); the second part includes the enumeration of Hungarian terminologies (1.2); and in the last part the typological system created by the author is described including the numbers and the definitions of the different type of vessels as well as the correlation with other frequently used typologies, with L. Barkóczi's catalogue among them (1.3).

The history of the research of glass vessels (2.1) is discussed in the second chapter concerning some problematic areas and Hungarian researches in this field (2.2).

The third chapter demonstrates the chemical and physical characteristics of glass, including the principal consistent and other additives (3.1). It also includes az overview on the materials and procedures used in ancient times. The importance and role of the chemical analysis are mentioned as well (3.2).

The fourth chapter is an extremely detailed description of the process of manufacturing, in which the production methods (4.1) and decorating techniques (4.2) are reviewed.

In the fifth chapter those archaeological sites and cemeteries are listed to which the finds, used as the basis of the dissertation, are related.

Chapters six to nine include the detailed analysis and classification of the collected and defined glass vessels from late Roman times. The analysis of the items follows the order of the typology created by the author and the functional categories. In the sixth chapter the tablewares, in the seventh the storage and transport vessels, in the eighth the unguentaria and in the ninth chapter the vessels with undefined function are profiled.

In the tenth chapter the variations of how glass vessels were put into graves are summarized, as well as the correspondence between them and other finds. Some interesting examples of recycling are also mentioned.

The eleventh chapter includes the analysis of the decoration systems. The twelfth chapter is an introduction on the capacity of the glass vessels and their connection with the Roman measures.

The thirteenth chapter presents the results of the research. The dissertation is closed with a bibliography and a catalogue of almost 1000 objects.

\section{Typology}

There has not been a consistent system for the definition of shapes, therefore it occurs that the same form is defined differently by the authors. L. Barkóczi's catalogue cannot be considered as complete, although it includes 556 vessels. He analysed only the intact vessels (although the research of the fragmentary vessels is also important), and the altogether 556 
finds derive from the entire period of Pannonia, whilst the dissertation includes 987 objects only from the 4 th and 5 th centuries $\mathrm{AD}$, indicating that the finds were examined on the basis of a wider database.

For this reason a new typology of the specific area and time period was necessary. To establish the new typology the works written by B. Rütti, H. M. E. Cool - J. Price, I. Lazar, G. Har ter, C. Isings, S. Cottam - J. Price, and S. Jennings were used by the author.

Although the groups of functions created by S. M. E. van Lith - K. Randsborg were followed, their notation of the categories has not been used. Instead, the types were marked with the first initials of their generally used Hungarian names, which seemed to be less complicated. So the types of the A1 category are marked with the letter T (Tál - bowl), the forms of the A2 category have the letter P (Pohár - cup), the A3 category is letter K (Korsó - jug), the B1 category is Pa (Palack - bottle), the B2 category has the letter F (Fazék - jar), and the C category is signed with the letter I (Illatszeres - unguentarium). Those fragments which could not be classified got the sign E (Egyéb - other), the same as used by I. Lazar és G. Harter.

The number of the types is complemented with another number which marks whether the vessel was decorated or not. Variant Nr. 1 stands for being undecorated and variant Nr. 2 for being decorated. Sometimes more decorations vary on the same vessel, so with this classification the combination of decorations can also be studied.

The last element of the typological system is the usage of A and B variants, which reflect important shaping details. In the case of bowls, cups, jars, bottles and perfume holders the variant $A$ means rims with cutting edge, while the variant $B$ marks fire-rounded rims. It denotes a different meaning in the case of jugs, where the rims were always fire-rounded, so the variants $\mathrm{A}$ and $\mathrm{B}$ reflect to the elaboration of the base.

\section{The main results of the dissertation}

The main results of the analysis, typology and classification as well as the chronological and geographical spread of the almost 1000 glass finds are summarized in this extract.

In the late Roman period of Pannonia mainly tablewares were produced: $57,9 \%$ of the finds belong to this category. Within this group drinking vessels dominate, since they amount to $45,5 \%$ of all vessels. Bowls and dishes (A1) basically lost their importance in comparison to the previous periods and can be found sporadically, they represent only $2,2 \%$ of the total finds. No tendency can be traced in the distribution of the bowls, they occured both along the limes and inside the province. Most bowls were found in Intercisa and Sopianae, but there are a few known from Ságvár, Aquincum, Brigetio, Scarbantia, Somogyszil, MórichidaKisárpás and Keszthely as well. The dishes from Aquincum and Brigetio can be dated to the beginning of the 4th century AD. The number of jugs for serving liquids (A3) is higher than the number of bowls, they represent $10,1 \%$ of the total finds. There is no difference in their distribution between certain territories; they were used along the limes as well as in larger cities (e.g. Solva, Intercisa, Sopianae, Aquincum, Mórichida-Kisárpás, Ságvár).

Amongst the storage and transport vessels only the group of bottles (B1) has notable figures; $20,2 \%$ of them are vessels with closed shape for storing liquids. They were found in Aquincum, Brigetio, Solva, Intercisa, Pilismarót, Ságvár, Sopianae in large amounts, that is, they 
concentrated in the Danube Bend and in the vicinity of Pécs while there are only one or two pieces from other sites. The usage of jars for storing foods (B2) ceased completely; only a single jar was found among the finds in the sarcophagus from Szekszárd.

The frequency of unguentaria decreased in comparison with their usage in the previous centuries, but they often appeared in late Roman times. They represent $18,8 \%$ of the analysed finds. Their presence was not rare, since they can be found in graves until the end of the 4 th century $\mathrm{AD}$, which means that their usage did not cease. In the early Roman period several unguentaria were placed to the same grave, while in the late Roman period only one perfume bottle was placed in one grave. Many unguentaria were found especially in Sopianae, Brigetio, around Solva, Aquincum, Bátaszék-Kövesd, Intercisa and Ságvár.

The last category includes objects which cannot be surely classified into any of the categories, such as flasks for pouring and vasa diatreta with controversial function. $2,5 \%$ of the vessels belong to this group.

Based on the classification to functional categories and the analysis the conclusion can be drawn that the proportion of category A2 increased extremely, followed by category A3, whereas the number of bowls diminished significantly.

According to S. M. E. van Lith and K. Randsborg any divergence from the average tendency regarding the frequency of the different categories in the late Roman period reflects the different economical conditions in different settlements. There is no deviation in Pannonia. A vast number of vessels occurred in Ságvár, Sopianae and its vicinity as well as the sites of the Danube Bend, especially in Solva. Ságvár is the only place where the rate of cups is not prominently higher than the rate of other categories.

Among the bowls the most typical form is the shallow convex bowl ( $\mathrm{T}$ 1) which might be decorated with wheel-cut lines or abrasion bands. The presence of convex bowls with indents is sporadic ( $\mathrm{T}$ 2). The third type is the shell-shaped, mould-blowed bowl (T 3). Only one cylindrical plate decorated with concentric circles at its bottom is known (T 4). The last category of bowls is represented by a single wide, flat cylindrical plate with facet-cutting ( $\mathrm{T}$ 5). The first three types were typical in the second half of the 4 th century $A D$, and may have also existed at the beginning of the 5th century $\mathrm{AD}$. The last two types are dated back to the beginning of the 4 th century $\mathrm{AD}$.

The most common glass objects as burial finds from the late Roman period were cups. Four hundred fifty-three vessels out of 987 represent this type, so nearly half the amount of the glass finds belong to this group. Until the last third of the 4th century AD the cups were generally of a good quality and they were made mainly of colourless or naturally coloured glass. However, at the end of the 4 th and 5 th centuries the dominant colours were the moss green and strong yellowish green and the material of the glass was generally worse and full of bubbles and strains. Considering the rims, cracked-off rims were formed and polished from the beginning of the 4th century $\mathrm{AD}$, although sometimes the cracked-off rims were left rough, which method became more and more dominant from the end of the century.

Slim beakers with curving body (P 1), slim beakers with curving wall and a base ring (P 2), slim, cylindrical beakers (P 3) and slim, cylindrical beakers with a base ring (P 4) can be related to the same workshop on the grounds of the likeness of their quality, colours, measures, 
decorations, rims, and their chronological and geographical spread. The workshop may have operated at the end of the 3rd century $\mathrm{AD}$, or rather in the first half of the 4 th century. These forms occurred especially in the vicinity of Arrabona, Brigetio and Aquincum in this short period of time. In Pannonia the hemispherical cups (P 5), which were widespread and popular throughout the Empire from the 4th until the beginning of the 5th century AD, are represented in large amounts. In Pannonia these cups were made of colourless glass in a good quality. They are partially decorated, sometimes including abrasion bands, the rims are usually cracked-off and unpolished. This type is more typical in the first two-third of the 4 th century AD.

The usage of hemispherical cups with a base ring (P 6) was also frequent between the first third of the 4th century and the 380's AD. Their export and expanse is similar to that of the previous type. One of the most important cup forms is the mould-blown convex cup with curved rim ("half-egg-shaped") (P 7), of which 67 pieces were found in Pannonia. They became popular from the middle of the 4th century, when they were made of natural green and colourless glass in a good quality. Their usage was at its peak at the end of the 4 th and the first half of the 5th century AD. They were made of a worse material in a strong yellowish green colour and after Pannonia had been surrendered they still remained popular in the Carpathian Basin during the 5th century. They were probably produced in Pannonia since the colour and quality of their material as well as the production process is identical to that of the optic-blowing, globular flasks, the cylindrical and pear shaped jugs and the smaller unguentaria, which were all found in large quantities. The representatives of $\mathrm{P} 7$ from the 5th century $\mathrm{AD}$ may have been products of a surviving glass workshop as their colour, form, quality, shaping of rims and decoration is similar to the ones from the end of the 4 th and beginning of the 5th century AD. The significant group of conical beakers (P 8-10) covered $35 \%$ of the finds. However, type P 8 , the conical beaker with a base ring, occurred in a smaller amount: there are 44 pieces listed in the catalogue. Its presence was typical in the first third of the 4th century AD and at the end of the century. Conical beakers with a flat base (P 9) can be found in the largest amount including 138 pieces, more than half of which are undecorated. Most undecorated pieces have vertical fire-rounded rims, while the decorated pieces have cracked-off rims. On the one hand, they were generally made of colourless or green glass with proper quality, on the other hand yellowish green and dark green coloured beakers with poor quality were also found. The decoration mostly includes abrasion brands, or it is the combination of abrasion brands and wheel-cut lines. Blue chips were rarely used as a decoration. The last type of the conical beakers is the one with small, flattened, rounded base (P 10). This type did not appear in many places in the Roman cemeteries in Pannonia, there are only nine examples of them. In all cases they were made of colourless or glass green material in a good quality. The rims are cracked-off, but polished afterwards. All of them are decorated, apart from the special piece from Mosdós with a decoration of facet-cutting cells. Pieces belonging to the P 10 type were decorated either with thick, wheel-cut lines, or with abrasion brands. Their difference from the other conical beakers in size, quality and decoration results in the conclusion that the former may have been used as lamps. There are only a few models of both the scyphos (P 11) and the Kowalk type beakers (P 12) known from the late Roman period, which might not have been local productions. Cylindrical beakers with stem and foot (P 13) from Pécs could be dated back to the second half of the 5 th century $\mathrm{AD}$, since this type became popular in this period of time. 
As for jugs, the most common type is the globular jug (K 1), which was typical in urban settlements. The majority of the pieces belonging to this type are decorated either with single horizontal trails under the rim or by optic-blowing. The indented globular jug belonging to this group with decorated base ring found in Savaria is quite special. This type existed from the first third of the 4th century AD in Pannonia, and was widely used in the second half of the century, but strong yellowish green versions of it still occurred during the first half of the 5th century AD. Cylindrical jugs (K 2) were typical along the limes between Mórichida and Intercisa and also in Pécs and Ságvár. Their decoration involves single horizontal trails under the rim, and thin spiral trails on the neck. The jug found in Ságvár is special for its single horizontal trail under the rim and for its handles, both of which were made of translucent, dark blue glass. Three-quarters of the pear shaped jugs (K 3) are decorated. Three of them are unique. The translucent dark blue jug from Mosdós is remarkable, it was made by optic-blowing and its decoration is a spiral trail on the neck. On the body of one of the jugs found in Brigetio diagonal ribs can be seen, and finally the decoration of a jug from Pécs consist of abrasion bands and facett-cutting ovals. This type was common in the 4 th century $\mathrm{AD}$, but was not popular in the 5 th century $\mathrm{AD}$.

The vessels for storage were grouped into eleven different types in the dissertation. The majority of these vessels can be classified into the first group of the globular bottles ( $\mathrm{Pa} 1)$. Three-quarters of them are undecorated. The rest were tipically decorated by optic-blowing or abrasion brands. The usage of this type was widespread from the end of the $3 \mathrm{rd}$ until the first half of the 5th century AD. The type of globular bottles with funnel mouth $(\mathrm{Pa} 2)$ is less frequent, and can be found only from the end of the 3rd to the first third of the 4th century $\mathrm{AD}$. One of its representatives with an unfinished rim consisting of cylindrical moiles was classified as a separate type by L. Barkóczi, whereas it can be ranged into this type. The group of $\mathrm{Pa} 3$ bottles includes only one piece with a funnel pulled-in neck, which was found in Majs. Examples of the last globular bottle type ( $\mathrm{Pa} 4)$ have a base ring and often two loophandles. Only a few specimens are known from the first half of the 4 th century AD. One of the bottles from Páty has double abrasion brands on its neck and doubled wheel-cut circles on its body. The next type is the cylindrical bottle with rounded shoulder ( $\mathrm{Pa} 5$ ), which was in use in the second half of the 4th and the beginning of the 5th century AD. They are usually made of strong yellowish green bad-quality glass and almost half of them are decorated by optic-blowing. They particularly occurred along the Danube Bend between Arrabona and Intercisa. The square bottles $(\mathrm{Pa} 6)$ are rare in the late Roman times in Pannonia. Their base usually does not have a pattern, but pontil marks can be identified on them, indicating that no separate base form took part in their production. The hexagonal undecorated bottles ( $\mathrm{Pa} 7)$ were not common either; only three pieces of them are known. The type of decagonal bottles ( $\mathrm{Pa} 8$ ) has only one example among the finds. The last group consisting bottles is the large cylindrical bottle with horizontal shoulders ( $\mathrm{Pa} 9$ ). These were made of strong yellow ish green glass full of tiny and dark specks. The surface of the bottles was usually divided into three or five fields by abrasion lines and decorated with facett-cutting ovals. Their usage can be dated back to the second half of the 4 th and the first half of the 5 th century AD. The amphora with a base knob ( $\mathrm{Pa} 10$ ) has opaque, blue and single horizontal trails under the rim and handles and was made of strong yellowish green glass. Its body is divided into three spheres containing some abrasion lines and cell shaped facet-cutting pattern. It can be dated from the last third of the 4 th to the first half of the 5 th century AD. The globular amphora 
with a base ring ( $\mathrm{Pa} 11)$ was made by optic-blowing and has opaque, dark blue base and handles. It can be dated back to the first half of the 4th century AD. Only one jar (F 1) is known from the sarcophagus of Szekszárd.

The group of unguentaria is the most various one regarding their shapes, but each type often includes only a single piece. The most frequent form is the globular unguentarium (I 1). This type is mainly asymmetric, the body of the vessel as well as the neck leans into one direction and they were made of glass of worse quality than the free blown vessels from previous periods. The presence of this type can be detected until the end of the 4 th century AD. The type of globular unguentarium with funnel mouth and rolled-in rim (I 2) is less frequent, and typical only in the 4th century. The small, indented globular unguentarium with wide, cylindrical neck (I 3) is represented only by one piece found at Ságvár from the 4th century AD. The group of drop shaped types (I 4) is also rare in the 4th century, and it consists of only three pieces. The same stands for conical unguent bottles (I 5). The forms of I 6-11 include indented unguent bottles, each form represented by a single find only. The differences between the types range from the various shapes of the bodies, the length and form of the necks and the shape of rims to the numbers of indents. The form I 12 contains only one specimen from Esztergom-Bánom. It is a small bottle with cylindrical body and neck and it has a funnel rim. Presently, no parallels of it are known. The form I 13 covers small jarshaped unguentaria with double curved rim, which is exemplified by one piece from Pécs and has no analogy so far. The form I 14 is an indented, hexagonal unguentarium. The single piece belonging to his type found in Brigetio has no parallel. The small, conical unguentaria with funnel rim were classified into the group I 15. I 16 contains the rod shaped, long, narrow type without neck. The form of flattened, globular unguentarium (I 17) has only one example from the 4th century AD. The most frequent type is the I 18, which is a long, narrow, pipette shaped unguent bottle. There is a small and a large variant. More than 50 pieces of this type were found in Pannonia. They were used from the second third of the 4 th until the first half of the 5th century AD. The form I 19 includes unguent balls without neck and rim. There is only one specimen found in Pécs. Its presence in the 4 th century AD is exceptional. The appearance of aryballoi (I 20) is rare in the late Roman times; there is only one piece of this type known from Ságvár, which was decorated with single horizontal trails.

The category E 1 embodies only one piece from a man's grave in Bátaszék-Kövesd. It is a small, cylindrical vessel with a base knob and a cutting enge rim, its body is decorated with abrasion bands. It was probably used as a lamp. The category E 2 includes the animal shaped vessels which were uncommon in the late Roman period. In the group E 3 small $(12-15 \mathrm{~cm}$ high), stretched, conical shaped vessels are listed, the bodies of which have a similar shape to the amphorae with a base knob, but with a funnel neck. Since they do not have handles and their necks are different, they cannot be classified as amphorae. One of them was found in Pécs, the other one is from the cemetery of Páty. Their exact parallels are not known; they could have been either drinking vessels, unguentaria or lamps. The piece from Pécs is decorated with abrasion brands on its neck and body, and small, tubular handles were attached to its shoulder so that it could be hung up. This proves that the representatives of this type may have been used as lamps. The category E 4 covers flask for pouring. They were frequent until the last third of the 4 th century AD, after that their presence became sporadic and only three pieces can be dated to the period from the end of the century to the beginning of the 
5th century AD. The category E 5 includes six small jar shaped vessels from the second half of the 4 th century AD. Vasa diatreta belong to the group E 6 .

It is also worth mentioning that some parts of some vessels were recycled, for example the base rings of jugs that were placed into children's graves as cups, or the rounded bases of large unguentaria (type Isings 105) which were reused as corks.

Glass making in Pannonia was not over with the surrender of the province, as the analysis of glass vessels found in cemeteries has proved that Roman type glass vessels were produced at least until the middle or the end of the 5th century AD. By the end of the century the demand for them had changed, and the variety of shapes reduced.

From the second half of the 4th century AD two regions are notable concerning the geographical spread of the glass vessels. One of them is along the limes between Arrabona and Intercisa, of which area the Danube Bend is the most remarkable since more than half of the vessels (53\%) were found in this region. The other zone was the city of Sopianae and its vicinity where $20 \%$ of the vessels were uncovered. These had a wide variety of forms. In the cemeteries of this area unique forms also occur. Their shapes have parallels from the second half of the 5th century AD throughout the Empire. The geographical extent indicates the existence of a late Roman glass workshop in the area of Pécs and the Danube Bend supplying these regions with vessels. L. Barkóczi's theory regarding the presence of a workshop in Csákvár can be neither excluded nor proven. The glass finds from the cemetery of Ságvár (inside the province) are quite special due to their unique forms, high quality and their functional proportions which are different from characteristics of vessels from other parts of the province. Apart from the regions mentioned above, the number of glass vessels drastically decreased in the late Roman period in Pannonia. 


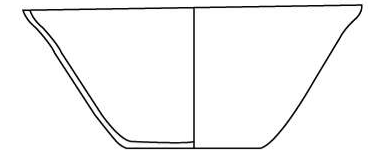

T1.1A

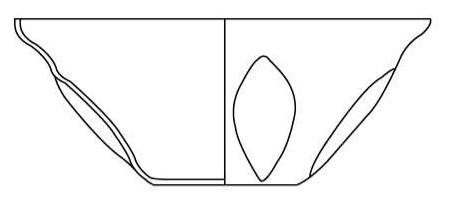

T2.1A

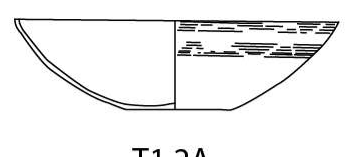

$\mathrm{T} 1.2 \mathrm{~A}$

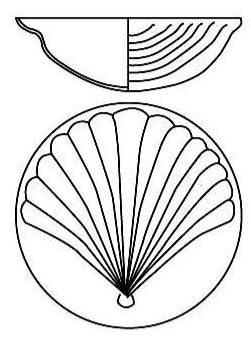

T3.2A
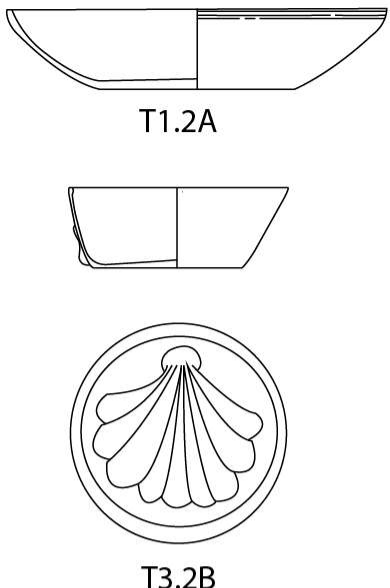

$\mathrm{T} 3.2 \mathrm{~B}$
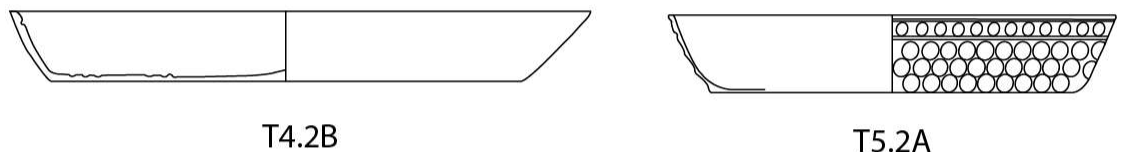

T5.2A
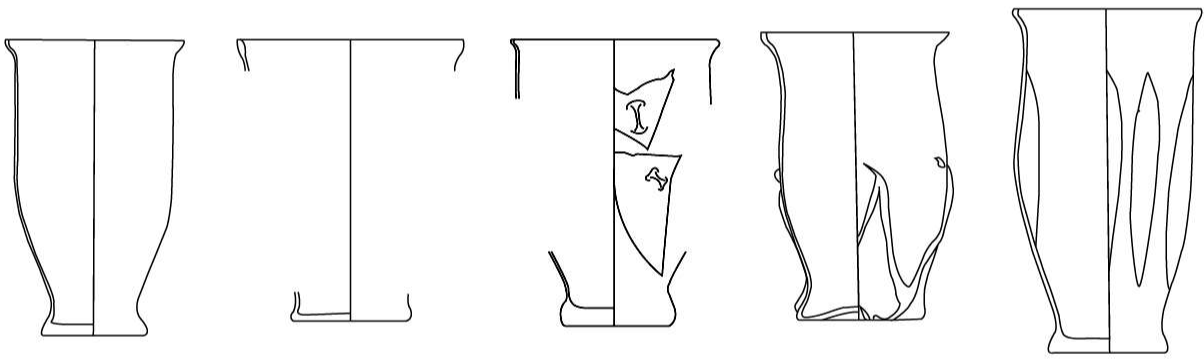

P1.1A

P1.1B

P1.2A

P1.2A

$\mathrm{P} 1.2 \mathrm{~A}$
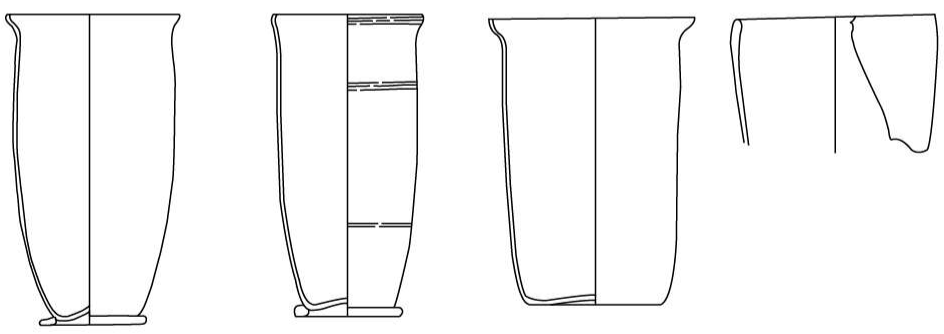

P3.1A

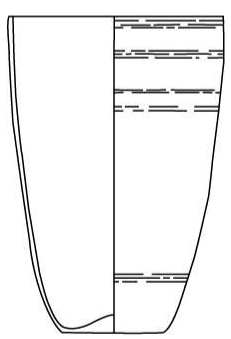

$\mathrm{P} 2.2 \mathrm{~A}$

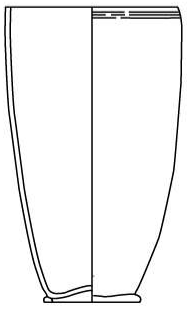

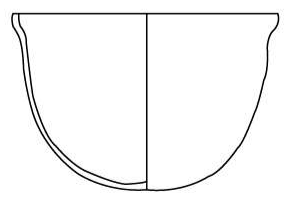

P5.1A

P3.2A

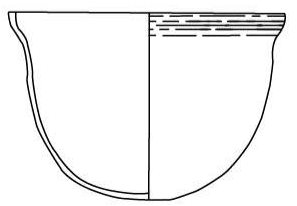

P5.2A

P4.1A

P4.1B

Fig. 1. 


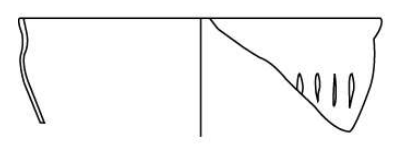

P5.2A

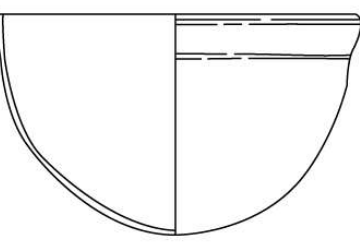

P5.2B

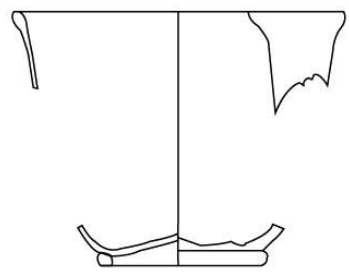

P6.1B

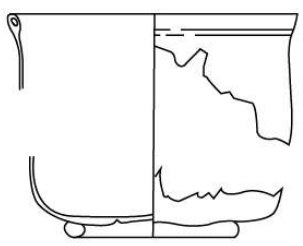

P6.2B

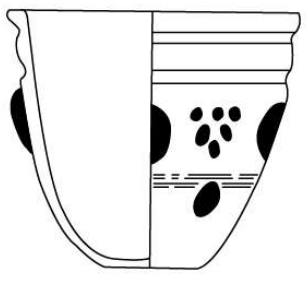

P7.2A

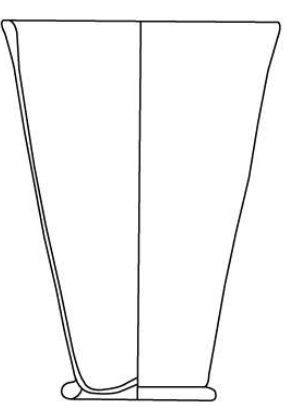

P8.1B

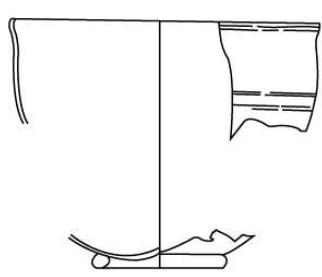

P6.2A

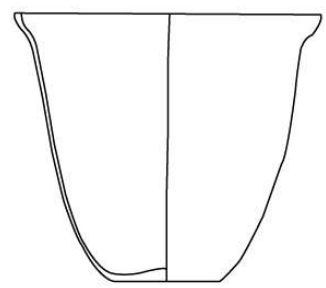

P7.1A

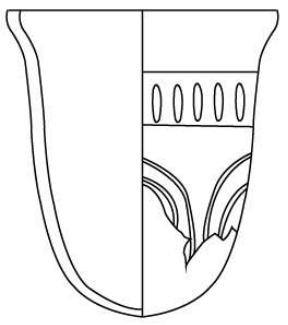

P7.2A

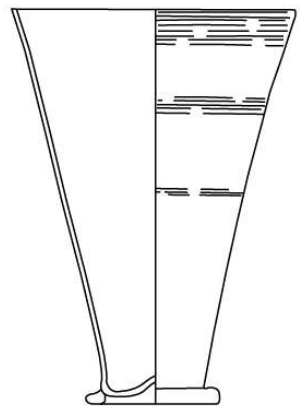

P8.2A

Fig. 2.

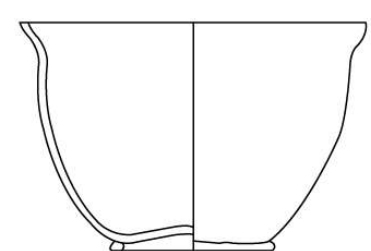

P6.1A

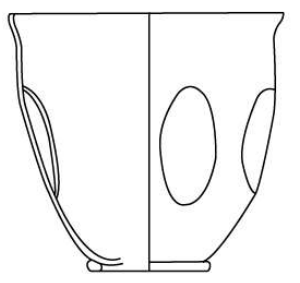

P6.2A

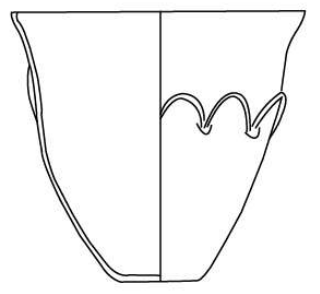

P7.2A

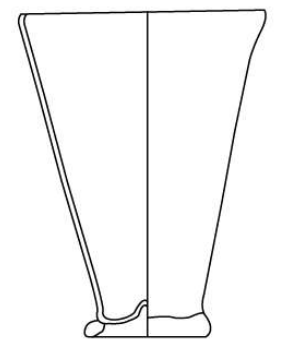

P8.1A

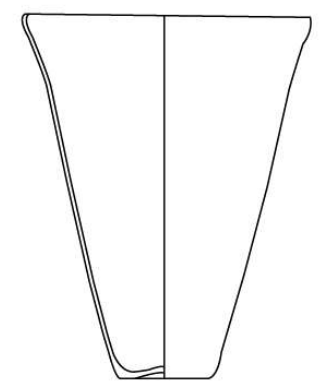

P9.1A 


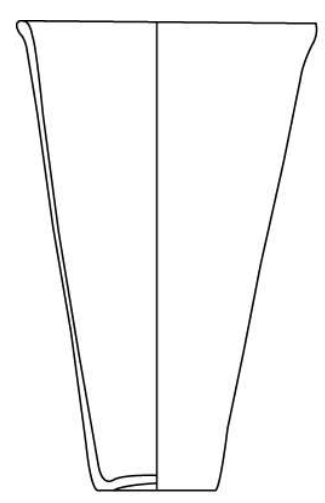

P9.1B

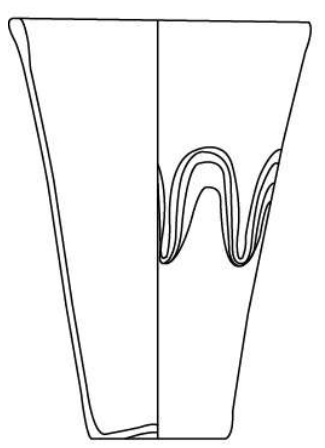

P9.2B

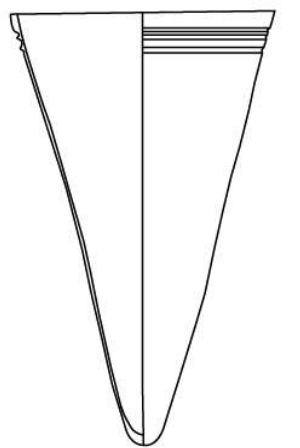

P10.2A

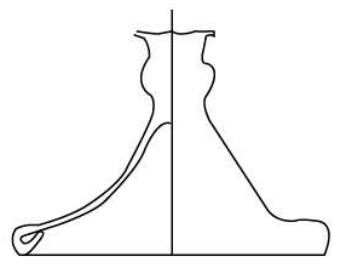

P13.1

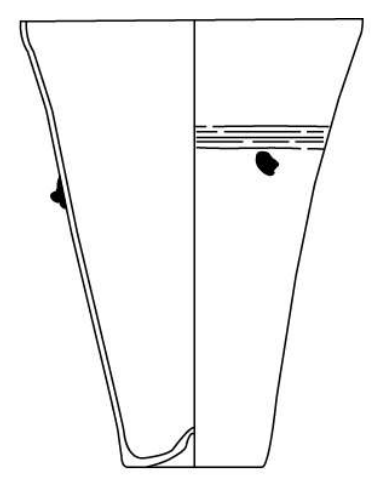

P9.2A

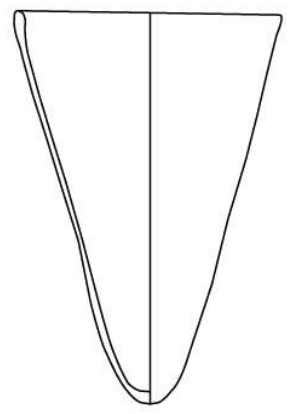

P10.1B
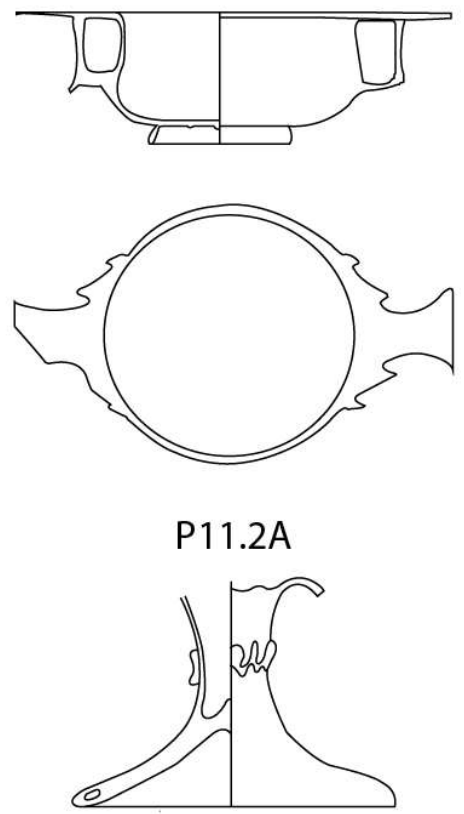

P13.2

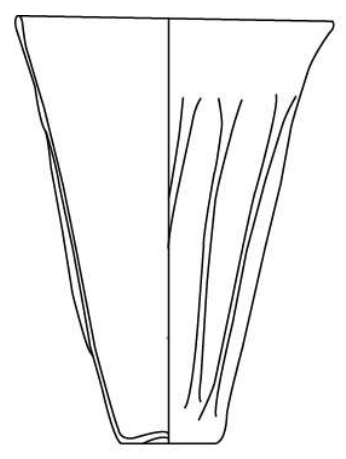

P9.2A

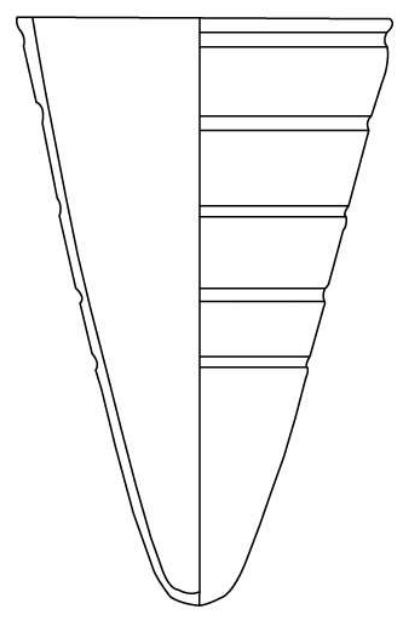

P10.2A

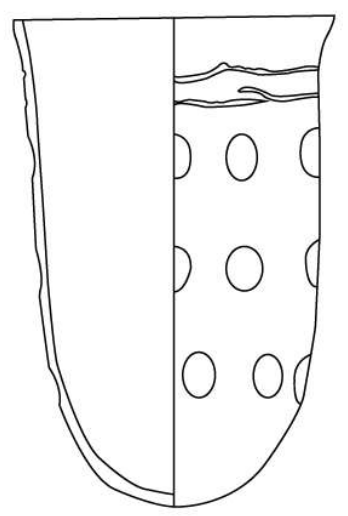

P12.2A

Fig. 3. 
Kata DÉvAI
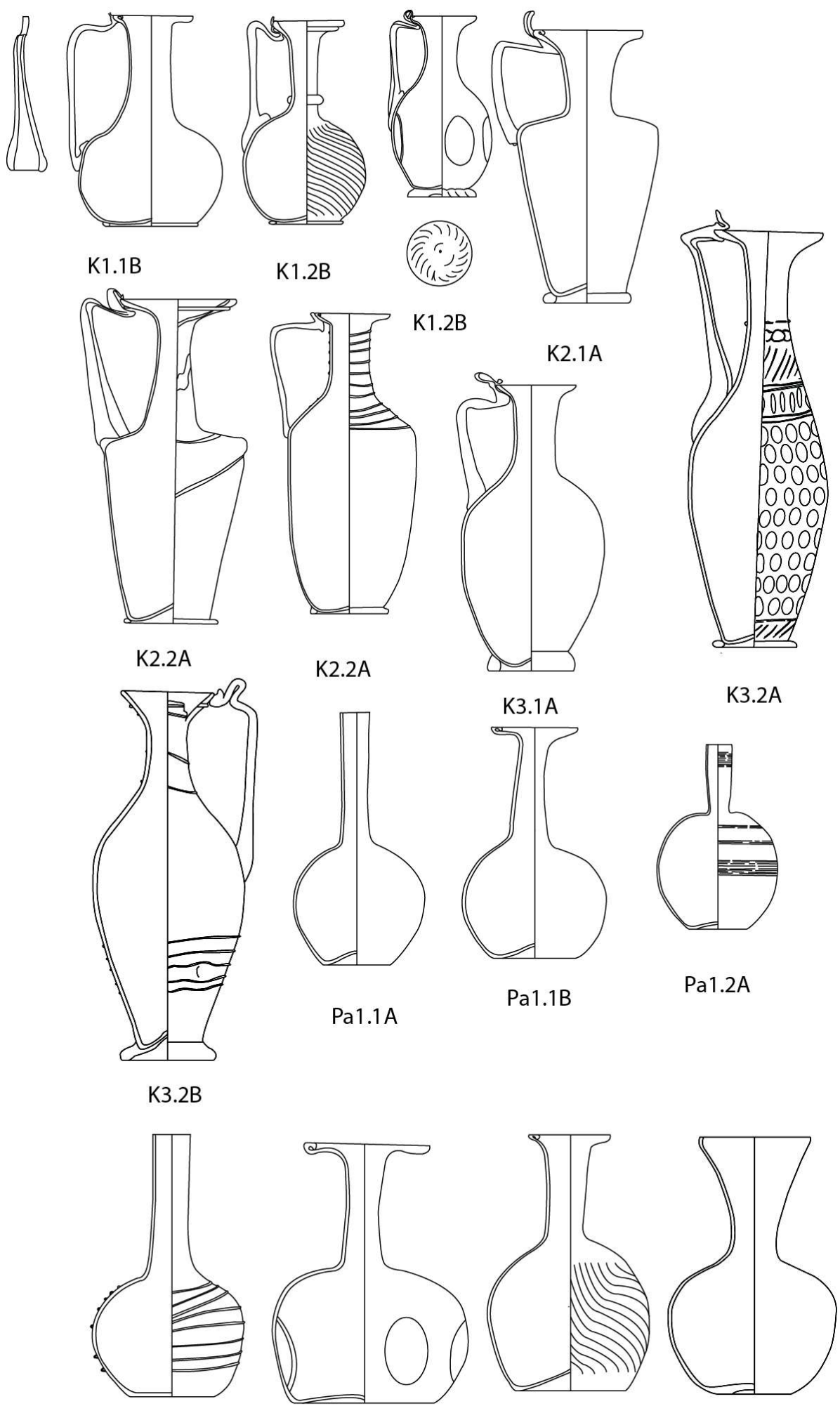

Pa1.1A

K3.2B
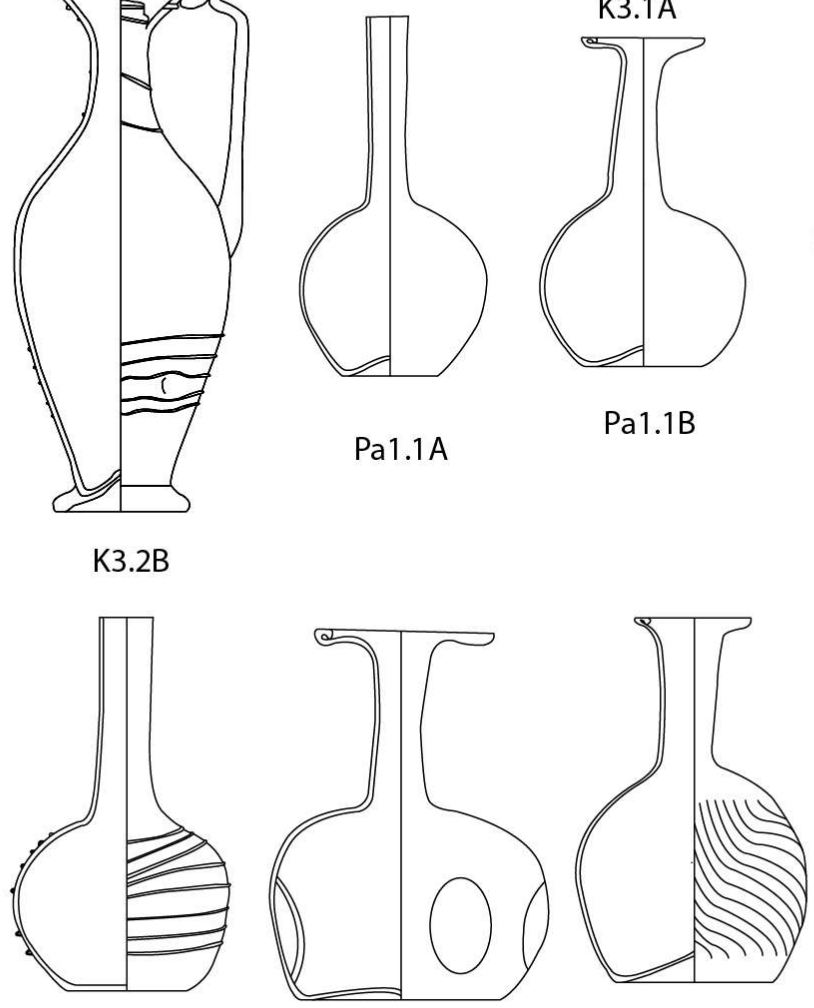

Pa1.2B

Pa2.1A

Pa1.2B

Fig. 4.

12 


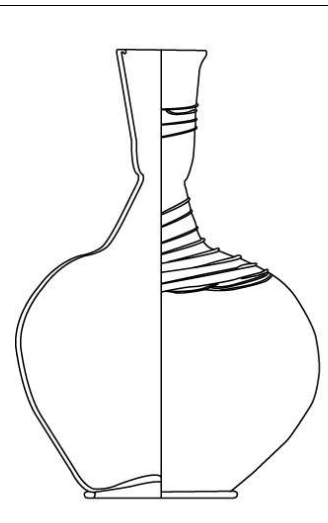

Pa3.2B

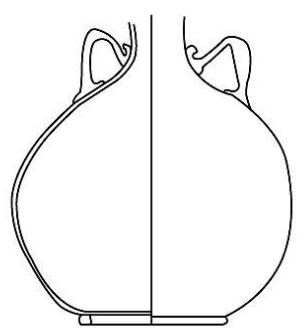

Pa4.1

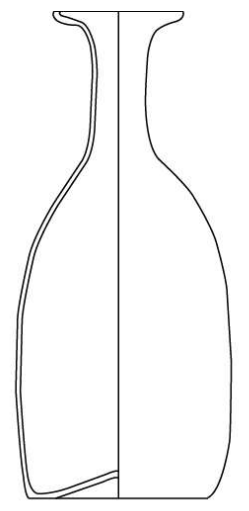

Pa5.1B

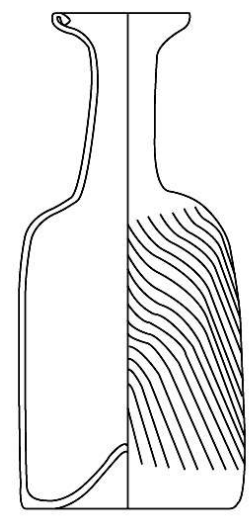

Pa1.2B

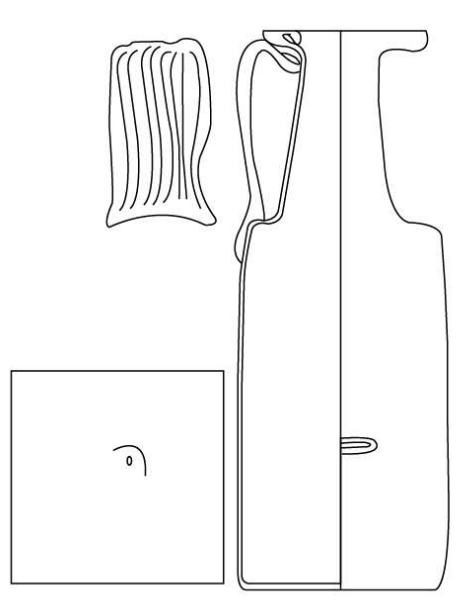

Pa6.1B

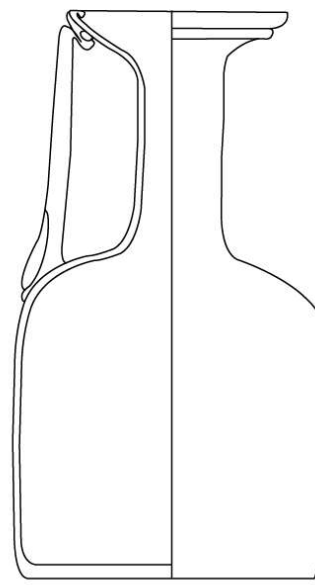

Pa8.2B

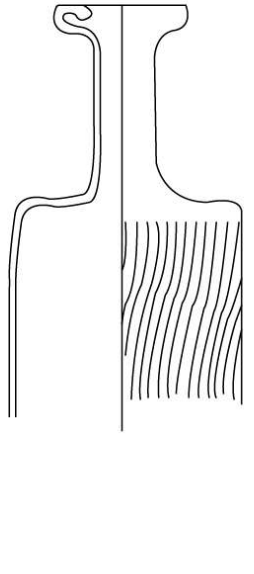

Рa6.2B

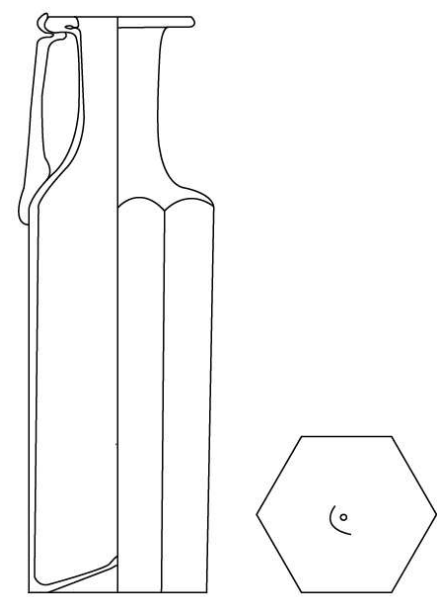

Pa7.1B

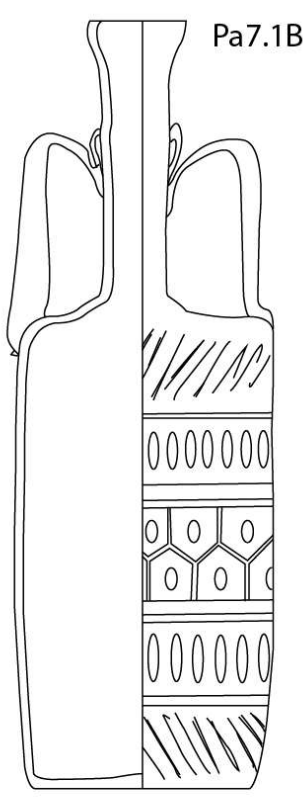

Pa9.2A

Fig. 5 . 


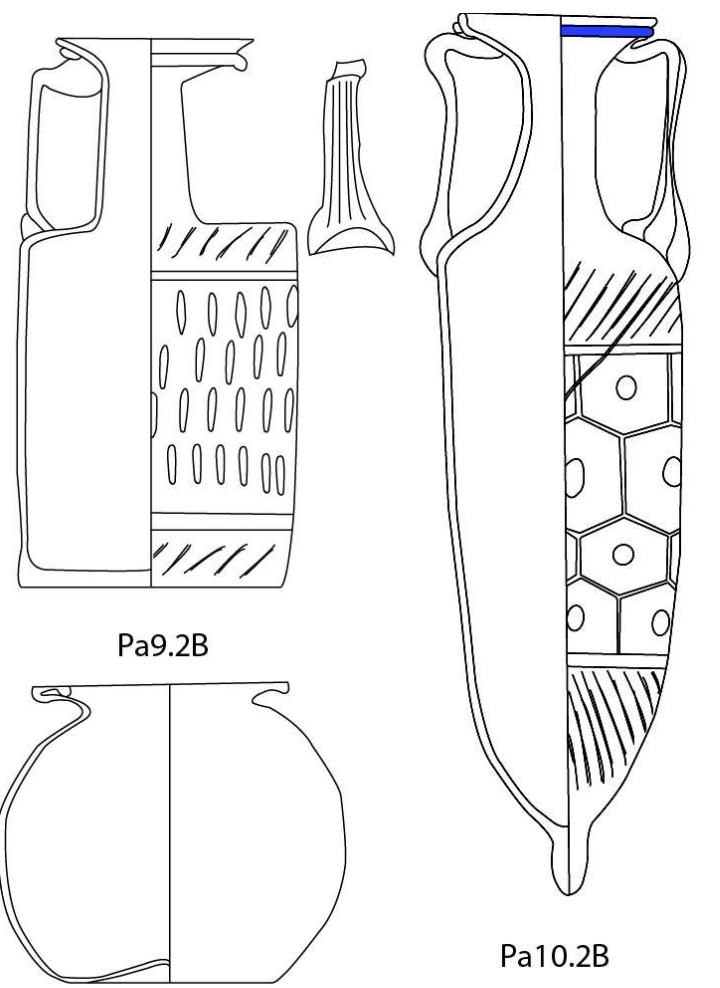

F1.1B
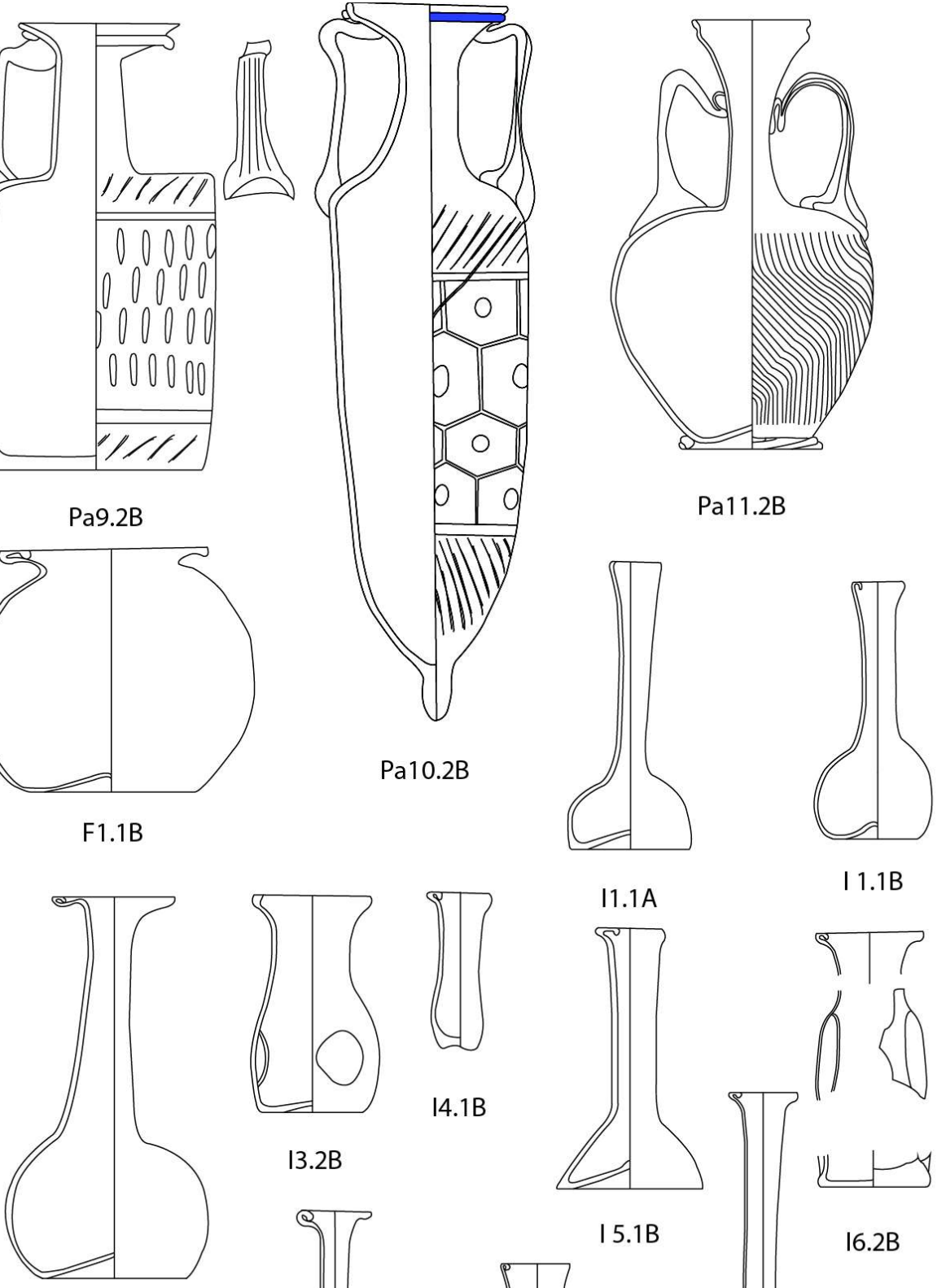

11.1A

I 1.1B
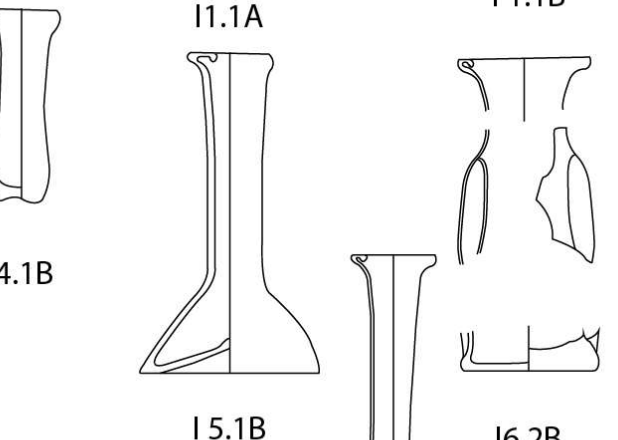

I2.1B

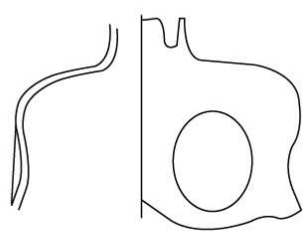

13.2B

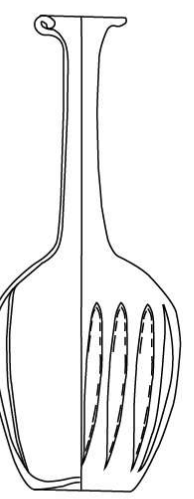

I8.2B

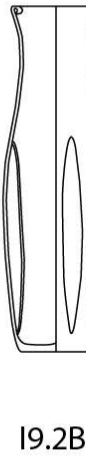

I 5.1B

16.2B

17.2

111.2

Fig. 6. 

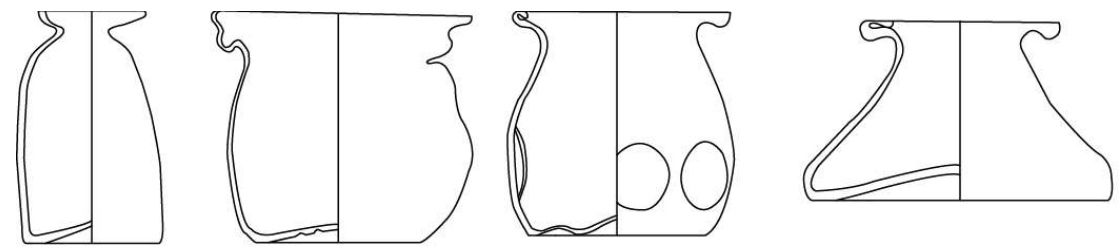

I12.1B

I13.1B

I14.2B

I15.1B
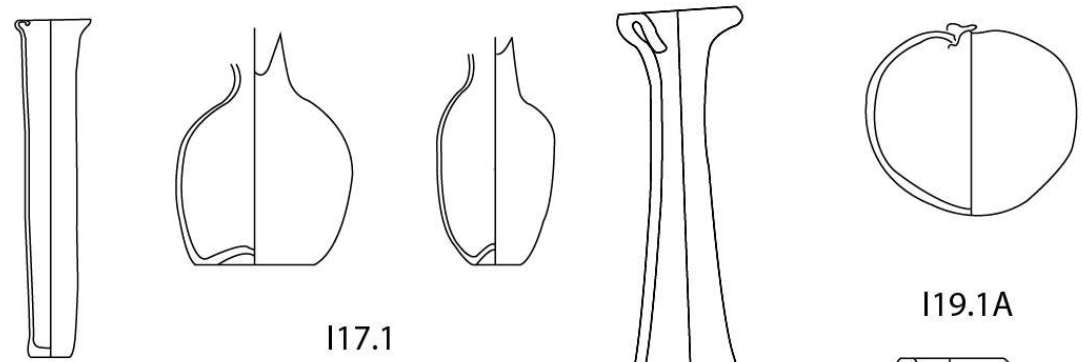

I19.1A

I16.1B

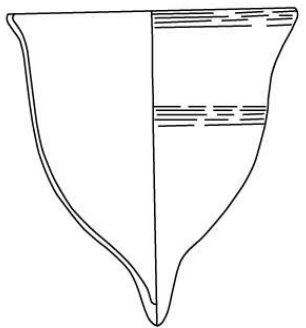

E1.2A

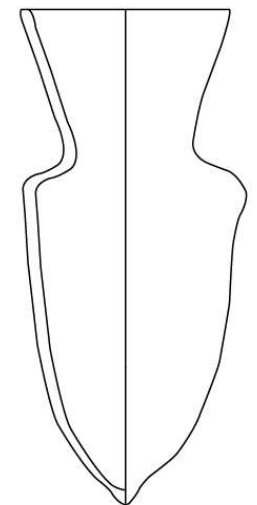

E3.1B

117.1
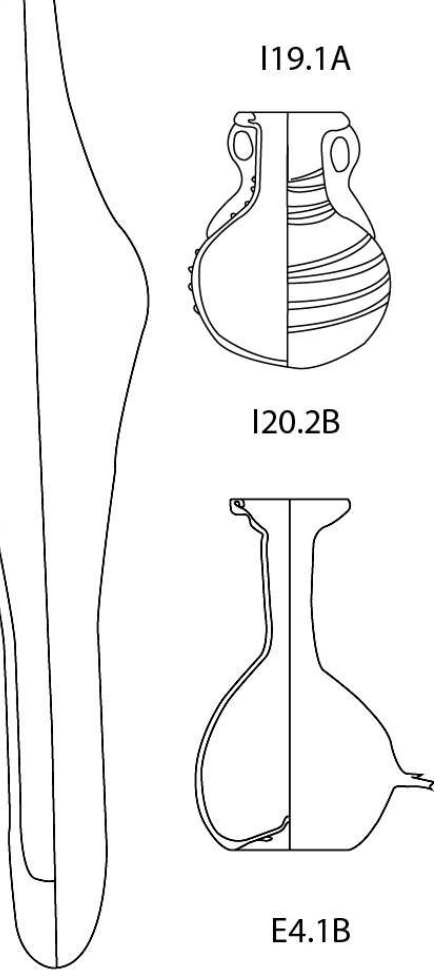

E4.1B

I18.1B

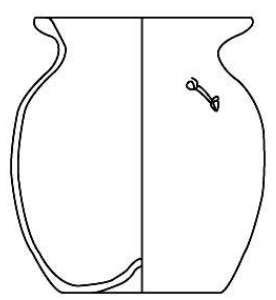

E5.1B

E6.2A

Fig. 7. (The drawing of E6.2A is after BARKóczi , L. 1988: Pannonische Glasfunde in Ungarn. Budapest, 219, Kat. Nr. 985). 